\title{
ANALISIS SISTEM PENGADAAN PROYEK KONSTRUKSI TERHADAP PENYERAPAN ANGGARAN PEMERINTAH KABUPATEN BADUNG
}

\author{
N. Gita Astadi $^{1}$, IN. Sutarja ${ }^{2}$, dan Mayun Nadiasa ${ }^{2}$
}

\begin{abstract}
Abstrak : Tingkat penyerapan anggaran suatu pemerintahan khususnya pada proyek konstruksi, menentukan optimal atau tidaknya pembangunan suatu daerah. Semakin cepat penyerapan anggaran proyek konstruksi, maka semakin cepat dirasakan manfaatnya. Tujuan penelitian dilakukan adalah untuk mengetahui tingkat penyerapan anggaran, mengetahui faktor-faktor pada sistem pengadaan proyek konstruksi yang mempengaruhi lambatnya penyerapan anggaran Pemerintah Kabupaten Badung serta upaya-upaya meminimalisir keterlambatan tersebut. Data diperoleh dari pihak-pihak yang terlibat dalam pengadaan proyek konstruksi melalui kuesioner sebagai instrumen penelitian. Selain itu data juga diperoleh melalui wawancara, observasi dan dokumentasi. Variabel penelitian yang digunakan sebanyak 38 variabel dan 60 orang sebagai responden. Analisis data yang dilakukan antara lain analisis deskriptif, analisis penyerapan anggaran dan analisis faktor. Sistem penilaian menggunakan skala likert, serta pengolahan data dengan SPSS. Dari hasil penelitian diperoleh tingkat penyerapan anggaran proyek konstruksi Pemerintah Kabupaten Badung Tahun Anggaran 2012 - 2013 masih belum sesuai dengan rencana tetapi sudah lebih meningkat dibandingkan tahun anggaran sebelumnya. Sedangkan dari hasil analisis faktor menggunakan SPSS, teridentifikasi faktor-faktor pada sistem pengadaan proyek konstruksi yang paling mempengaruhi lambatnya penyerapan anggaran yaitu ketakutan dan kehati-hatian para pihak dalam melaksanakan kegiatan pengadaan, adanya perubahan paket kegiatan, lambatnya penyusunan HPS, kurang lengkapnya dokumen pengadaan, kesalahan penafsiran peraturan pengadaan dan lambatnya proses pengadaan. Dan upaya yang paling efektif untuk meningkatkan penyerapan anggaran adalah menetapkan standar komunikasi, koordinasi dan sinkronisasi dalam pengadaan proyek konstruksi dengan semua pihak yang terlibat didalamnya.
\end{abstract}

Kata kunci: sistem pengadaan, proyek konstruksi, penyerapan anggaran, analisis faktor.

\section{ANALYSIS ON THE PROCUREMENT SYSTEMS OF THE CONSTRUCTION PROJECTS TOWARDS THE BUDGET ABSORPTION OF THE LOCAL GOVERNMENT OF THE BADUNG REGENCY}

\begin{abstract}
The rate of absorption of a government budget, especially on the construction projects, determine whether or not the optimal development of a region. The faster the budget absorption of the construction projects, the faster the perceived benefits. The purpose of the study was to determine the rate of the budget absorption, to find out the factors in the construction project procurement systems that affect the slow budget absorption of the Local Government of the Badung Regency as well as the efforts to minimize such delays. The data were obtained from the parties involved in the procurement of the construction projects through questionnaires as the research instruments. In addition, the data were also obtained through interviews, observations and documentations. The variables used in the study were 38 variables and 60 persons as the respondents. The data analysis was conducted through descriptive analysis, absorption analysis and factor analysis. The scoring system used a Likert scale, and data processing was conducted by SPSS. The findings of the study show that the rate of absorption of the Badung Regency Government's construction projects for Fiscal Year 2012 - 2013 was not in accordance with the plan, but the increase was more than that of the previous fiscal year. While the results of the factor analysis by using SPSS indicate that the factors that affecting the slow absorption budget in the procurement system of most construction projects are: the fear and caution of the parties in carrying out procurement activities, the change in the activity package, the slow preparation of the Owner's Estimate (OE), the incomplete procurement documents, the misrepresentation of the procurement regulations and the slow process of procurements. And the most effective effort to enhance the budget absorption are the determination of the communication standards, the coordination and the synchronization in the procurement of construction projects with all parties involved in the procurement systems.
\end{abstract}

Keywords: the procurement systems, the construction projects, the budget absorption, the factor analysis.

\footnotetext{
${ }^{1}$ Mahasiswa Program Magister Teknik Sipil, Fakultas Teknik, Universitas Udayana, Denpasar

${ }^{2}$ Staf Pengajar Program Magister Teknik Sipil, Fakultas Teknik, Universitas Udayana, Denpasar
} 


\section{PENDAHULUAN}

\section{Latar Belakang}

Ukuran keberhasilan pelaksanaan pengadaan proyek konstruksi adalah perolehan barang dan jasa yang tepat sesuai dengan kebutuhan dan waktu yang telah ditentukan. Sedangkan cara untuk merealisasi dana anggaran, acuannya adalah peraturan perundangan yang berlaku tentang sistem pencairan anggaran, sehingga ukuran keberhasilannya adalah tingkat penyerapan dana anggaran.

Jika melihat perjalanan penyerapan anggaran dari tahun ke tahun, bukanlah hal yang aneh lagi dimana setiap penyelenggara pemerintahan selalu mengebut penyerapannya pada setiap akhir tahun anggaran. Lambatnya penyerapan anggaran, baik APBN maupun APBD, bukanlah masalah baru dalam dunia keuangan pemerintahan. Disetiap tahunnya, penyerapan anggaran biasanya menumpuk pada akhir tahun. Penelitian ini akan meninjau pada bidang pengadaan, karena pengadaan merupakan salah satu tahapan yang memakan waktu paling banyak dalam merealisasikan suatu proyek konstruksi. Sistem pengadaan khususnya proyek konstruksi pemerintah telah mengalami perkembangan. Dimulai dari sistem konvensional sampai dengan sistem $e$ procurement.

Pada sistem pengadaan, tentunya terdapat faktor-faktor yang mempengaruhi lambatnya penyerapan anggaran. Hal ini perlu dikaji lebih lanjut sebab penyerapan anggaran proyek konstruksi menjadi faktor penting karena merupakan urat nadi bagi suatu daerah dalam menjalankan pemerintahan dan roda perekonomian.

Setelah diketahui faktor-faktor pada sistem pegadaan proyek konstruksi yang mempengaruhi lambatnya penyerapan anggaran, maka harus segera diupayakan solusi-solusi untuk mengatasi keterlambatan penyerapan anggaran sehingga selanjutnya keterlambatan penyerapan anggaran dapat diminimalisir.

\section{Tujuan Penelitian}

Tujuan penelitian ini adalah:

1. Untuk mengetahui tingkat penyerapan anggaran proyek konstruksi Tahun Anggaran 2012 - 2013 di Pemerintah Kabupaten Badung.

2. Untuk mengetahui faktor-faktor apa saja pada sistem pengadaan proyek konstruksi yang mempengaruhi lambatnya penyerapan anggaran Pemerintah Kabupaten Badung.

3. Untuk mengetahui upaya-upaya apa saja yang dapat dilakukan terhadap sistem pengadaan proyek konstruksi untuk mengurangi terjadinya keterlambatan penyerapan anggaran di Pemerintah Kabupaten Badung.

\section{KAJIAN PUSTAKA}

\section{Pengertian Proyek Konstruksi}

Proyek merupakan suatu usaha dengan tujuan tertentu dengan waktu dan sumber daya terbatas. Sedangkan konstruksi merupakan susunan atau model suatu bangunan yang merupakan hasil dari suatu kegiatan proyek. Jadi proyek konstruksi adalah mendirikan suatu bentuk bangunan dengan waktu tertentu dengan menggunakan sumber daya proyek yang terbatas.

\section{Tahapan Proyek Konstruksi}

Kegiatan proyek secara umum terdiri dari tahapan: (Ervianto, 2005)

1. Tahap studi kelayakan (feasibility study)

2. Tahap penjelasan (briefing)

3. Tahap perancangan (design)

4. Tahap pengadaan (procurement)

5. Tahap pelaksanaan (construction)

6. Tahap pemeliharaan dan persiapan

\section{Pengertian Pengadaan}

Pengadaan barang/jasa berdasarkan Perpres No. 70 Tahun 2012 adalah "kegiatan untuk memperoleh barang/jasa oleh Kementerian/Lembaga/Satuan Kerja Perangkat Daerah/Institusi yang prosesnya dimulai dari perencanaan kebutuhan sampai diselesaikannya seluruh kegiatan untuk memperoleh barang/jasa".

\section{Sistem Pengadaan}

Sistem pengadaan adalah suatu cara untuk mendapatkan barang dan jasa yang dibutuhkan dengan menggunakan metode dan proses tertentu. Ada dua macam sistem pengadaan yang umum digunakan, yaitu sistem konvensional dan sistem $e$ procurement.

Pihak - Pihak yang Terlibat dalam Pengadaan

Menurut Perpres nomor 70 tahun 2012, menerangkan bahwa ada beberapa pihak yang terlibat diantaranya:
a. Pengguna Anggaran/Kuasa Pengguna Anggaran (PA/KPA).

b. Pejabat Pembuat Komitmen (PPK). 
c. Unit Layanan Pengadaan/Pejabat Pengadaan (ULP/PP).

d. Panitia/Pejabat Penerima Hasil Pekerjaan (PPHP).

\section{Pengertian Anggaran}

Menurut Mardiasmo (2002), anggaran adalah sebagai sebuah proses yang dilakukan oleh organisasi sektor publik untuk mengalokasikan sumber daya yang dimilikinya pada kebutuhan-kebutuhan yang tidak terbatas. Selain itu anggaran berfungsi sebagai alat kontrol atau pengawasan, baik terhadap pendapatan maupun pengeluaran pada masa yang akan datang.

\section{Penyerapan Anggaran}

Penyerapan anggaran merupakan salah satu indikator yang dapat menunjukkan berhasilnya program atau kebijakan yang dilakukan pemerintah. Rasio realisasi terhadap anggaran mencerminkan terserapnya anggaran dalam melakukan berbagai program yang telah ditetapkan. Dengan pertimbangan ini maka kemampuan menyerap anggaran oleh pemerintah daerah dapat menjadi indikator kinerja pemerintah kota/kabupaten.

\section{METODE PENELITIAN}

Penelitian dirancang dengan mengggunakan pendekatan penelitian kualitatif yang dimana lebih bersifat deskriptif. Data yang terkumpul berbentuk kata-kata atau gambar sehingga tidak menekankan pada angka. Data yang digunakan merupakan data kuantitatif dan kualitatif. Menurut sumbernya, data penelitian berupa data primer maupun data sekunder.

\section{Lokasi}

Sesuai dengan dasar-dasar pemikiran pada latar belakang masalah, maka lokasi penelitian adalah di Pemerintahan Kabupaten Badung dan meninjau proyek konstruksi Tahun Anggaran 2012 - Tahun Anggaran 2013. Hal ini dengan pertimbangan Pemerintah Kabupaten Badung merupakan satu-satunya kabupaten di Provinsi Bali dengan APBD tertinggi.

\section{Variabel Penelitian}

Variabel yang digunakan dalam penelitian ini adalah:

Tabel 1 Variabel - Variabel Penelitian

\begin{tabular}{|c|c|c|c|c|}
\hline NO & & VARIABEL & & ATRIBUT \\
\hline 1 & $\begin{array}{l}\text { Ketakutan } \\
\text { dalam }\end{array}$ & $\begin{array}{l}\text { dan kehati-hatian } \\
\text { melaksanakan }\end{array}$ & $\begin{array}{l}\text { PA/KPA } \\
\text { kegiatan }\end{array}$ & $\mathrm{X} 1$ \\
\hline
\end{tabular}

\begin{tabular}{|c|c|c|}
\hline NO & VARIABEL & ATRIBUT \\
\hline & pengadaan & \\
\hline 2 & $\begin{array}{l}\text { Kurangnya sosialisasi tata cara } \\
\text { pengadaan berdasarkan peraturan yang } \\
\text { berlaku kepada PA/KPA }\end{array}$ & $\mathrm{X} 2$ \\
\hline 3 & $\begin{array}{l}\text { SDM sebagai pejabat PA/KPA kurang } \\
\text { kompeten }\end{array}$ & $\mathrm{X} 3$ \\
\hline 4 & $\begin{array}{l}\text { Adanya perubahan paket kegiatan oleh } \\
\text { PA/KPA }\end{array}$ & $\mathrm{X} 4$ \\
\hline 5 & $\begin{array}{l}\text { DIPA terlambat diterima oleh } \\
\text { PA/KPA }\end{array}$ & $\mathrm{X} 5$ \\
\hline 6 & $\begin{array}{l}\text { Keterlambatan dalam penetapan PPK } \\
\text { oleh PA/KPA }\end{array}$ & X6 \\
\hline 7 & $\begin{array}{l}\text { Kesulitan PPK dalam menentukan } \\
\text { HPS karena kurangnya keahlian }\end{array}$ & $\mathrm{X} 7$ \\
\hline 8 & $\begin{array}{l}\text { Lambatnya proses penyusunan HPS } \\
\text { oleh PPK }\end{array}$ & $\mathrm{X} 8$ \\
\hline 9 & $\begin{array}{l}\text { Kurang lengkapnya dokumen yang } \\
\text { dimil iki PPK untuk keperluan } \\
\text { pengadaan }\end{array}$ & $\mathrm{X} 9$ \\
\hline 10 & $\begin{array}{l}\text { Kurangnya sosialisasi tata cara } \\
\text { pengadaan berdasarkan peraturan yang } \\
\text { berlaku kepada PPK/PPTK }\end{array}$ & $\mathrm{X} 10$ \\
\hline 11 & $\begin{array}{llr}\text { Ketakutan dan } & \text { kehati-hatian } \\
\text { PPK/PPTK dalam } & \text { melaksanakan } \\
\text { kegiatan pengadaan } & \end{array}$ & $\mathrm{X} 11$ \\
\hline 12 & $\begin{array}{l}\text { SDM sebagai PPK/PPTK kurang } \\
\text { kompeten }\end{array}$ & $\mathrm{X} 12$ \\
\hline 13 & $\begin{array}{l}\text { Keterlambatan dalam } \\
\text { penandatanganan kontrak oleh PPK }\end{array}$ & $\mathrm{X} 13$ \\
\hline 14 & $\begin{array}{l}\text { Keterlambatan dalam penyusunan } \\
\text { laporan kegiatan oleh PPK/PPTK }\end{array}$ & $\mathrm{X} 14$ \\
\hline 15 & $\begin{array}{l}\text { Adanya perubahan paket kegiatan oleh } \\
\text { PPK }\end{array}$ & $\mathrm{X} 15$ \\
\hline 16 & $\begin{array}{l}\text { Adanya perubahan jadwal kegiatan } \\
\text { oleh PPK }\end{array}$ & $\mathrm{X} 16$ \\
\hline 17 & $\begin{array}{l}\text { Keterlambatan penyusunan Kerangka } \\
\text { Acuan Kerja oleh PPK }\end{array}$ & $\mathrm{X} 17$ \\
\hline 18 & $\begin{array}{l}\text { Keterbatasan pejabat yang bersertifikat } \\
\text { untuk PPK/PPTK }\end{array}$ & $\mathrm{X} 18$ \\
\hline 19 & $\begin{array}{l}\text { Keterbatasan panitia pengadaan/ULP } \\
\text { yang bersertifikat }\end{array}$ & X19 \\
\hline 20 & $\begin{array}{l}\text { Keengganan untuk menjabat panitia } \\
\text { pengadaan/ULP }\end{array}$ & $\mathrm{X} 20$ \\
\hline 21 & $\begin{array}{l}\text { Tidak seimbangnya risiko pekerjaan } \\
\text { dengan imbalan yang diterima oleh } \\
\text { panitia pengadaan/ULP }\end{array}$ & $\mathrm{X} 21$ \\
\hline 22 & $\begin{array}{l}\text { Lamanya proses penyiapan dokumen } \\
\text { pengadaan oleh ULP }\end{array}$ & $\mathrm{X} 22$ \\
\hline 23 & $\begin{array}{l}\text { Lambatnya proses pengadaan di ULP } \\
\text { akibat adanya gagal lelang/tender } \\
\text { ulang }\end{array}$ & $\mathrm{X} 23$ \\
\hline 24 & $\begin{array}{l}\text { Lambatnya proses pengadaan di ULP } \\
\text { akibat lelang masih dalam masa } \\
\text { sanggah dan proses hukum }\end{array}$ & $\mathrm{X} 24$ \\
\hline 25 & $\begin{array}{l}\text { Kurangnya sosialisasi tata cara } \\
\text { pengadaan berdasarkan peraturan yang } \\
\text { berlaku kepada panitia } \\
\text { pengadaan/ULP }\end{array}$ & $\mathrm{X} 25$ \\
\hline 26 & $\begin{array}{l}\text { Adanya rangkap tugas } \\
\text { pengadaan/ULP } \\
\text { kedinasan }\end{array}$ & $\mathrm{X} 26$ \\
\hline 27 & $\begin{array}{l}\text { Kesalahan penafsiran terhadap isi } \\
\text { peraturan pengadaan yang berlaku } \\
\text { oleh panitia pengadaan/ULP }\end{array}$ & $\mathrm{X} 27$ \\
\hline 28 & $\begin{array}{l}\text { Ketakutan dan kehati-hatian panitia } \\
\text { pengadaan/ULP dalam melaksanakan } \\
\text { kegiatan pengadaan }\end{array}$ & $\mathrm{X} 28$ \\
\hline 29 & $\begin{array}{l}\text { SDM sebagai panitia pengadaan/ULP } \\
\text { kurang kompeten }\end{array}$ & $\mathrm{X} 29$ \\
\hline 30 & $\begin{array}{l}\text { Keterlambatan dalam penyusunan } \\
\text { laporan kegiatan oleh ULP }\end{array}$ & $\mathrm{X} 30$ \\
\hline 31 & $\begin{array}{l}\text { Lambatnya proses pengadaan karena } \\
\text { jumlah SDM di ULP kurang memadai }\end{array}$ & $\mathrm{X} 31$ \\
\hline 32 & $\begin{array}{l}\text { Adanya perubahan paket kegiatan } \\
\text { ketika dalam proses pengadaan di ULP }\end{array}$ & $\mathrm{X} 32$ \\
\hline 33 & $\begin{array}{l}\text { Adanya perubahan jadwal kegiatan } \\
\text { pengadaan oleh panitia } \\
\text { pengadaan/ULP }\end{array}$ & $\mathrm{X} 33$ \\
\hline 34 & $\begin{array}{l}\text { Terlambatnya penyusunan jadwal } \\
\text { pelaksanaan pengadaan oleh panitia }\end{array}$ & X34 \\
\hline
\end{tabular}




\begin{tabular}{clc}
\hline NO & \multicolumn{1}{c}{ VARIABEL } & ATRIBUT \\
\hline 35 & $\begin{array}{l}\text { pengadaan/ULP } \\
\text { Kurangnya sosialisasi tata cara } \\
\text { pengadaan berdasarkan peraturan yang } \\
\text { berlaku kepada PPHP }\end{array}$ & X35 \\
36 & $\begin{array}{l}\text { SDM sebagai PPHP kurang kompeten } \\
37\end{array}$ & $\begin{array}{l}\text { Keterlambatan dalam penyusunan } \\
\text { laporan kegiatan oleh PPHP }\end{array}$ \\
38 & $\begin{array}{l}\text { Keterlambatan penyampaian laporan } \\
\text { karena jumlah SDM sebagai PPHP } \\
\text { kurang memadai }\end{array}$ & X37 \\
\hline Sumber: Data primer dan data sekunder diolah, 2013
\end{tabular}

Metode dan Teknik Pengumpulan Data

Pengumpulan data dilakukan dengan menggunakan kuesioner yang didahului dengan melakukan uji validitas dan reliabilitas instrumen penelitian sebelum disebarkan pada responden. Juga dengan melakukan in-depth interview terhadap informan ahli (judgment expert) mengenai hal-hal yang akan diteliti. Selain itu dilakukan teknik observasi serta dokumentasi.

\section{Metode dan Teknik Analisis Data}

Teknik analisis data menggunakan analisis statistik deskriptif, analisis tingkat penyerapan anggaran untuk mengetahui gambaran penyerapan anggaran proyek konstruksi Pemerintah Kabupaten Badung Tahun Anggaran 2012 - Tahun Anggaran 2013. Serta dilakukan analisis faktor untuk mengetahui faktor-faktor pada sistem pengadaan proyek konstruksi yang mempengaruhi lambatnya penyerapan anggaran.

Analisis faktor dilakukan dengan melakukan penilaian hasil kuesioner menggunakan skala likert, kemudian dilakukan analisis faktor dengan bantuan program Statistical Package for Social Science (SPSS) for Windows versi 15.0 untuk mempermudah, mempercepat dan keakuratan analisis yang diperoleh sehingga dapat menjawab permasalahan yang telah dirumuskan dalam penelitian.

\section{HASIL DAN PEMBAHASAN}

Dari hasil uji validitas instrumen penelitian terhadap 30 sampel dengan 38 variabel pertanyaan menggunakan Corrected Item-Total Correlation, diperoleh $\mathrm{r}\left({ }_{\text {hitung }}\right)>$ $\mathrm{r}\left({ }_{\text {tabel }}\right)$ dengan tingkat signifikansi 5\% sehingga instrumen dikatakan valid. Sedangkan hasil pengujian dengan SPSS diperoleh koefisien Alpha Cronbach sebesar 0,995. Ini berarti instrumen dikatakan sudah reliabel karena koefisien Alpha Cronbach >0,6

\section{Analisis Deskriptif}

Dari kuesioner yang disebar, diperoleh:

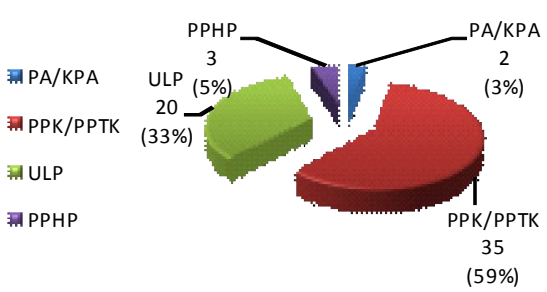

Gambar 1 Gambaran Umum Responden

Dari hasil analisis dengan SPSS diperoleh gambaran secara menyeluruh mengenai data penelitian yang diperoleh berupa jenis variabel dengan ringkasan statistiknya seperti mean, median, modus, standar deviasi, dan frequencies.

\section{Analisis Penyerapan Anggaran}

Hasil olah data yang diperoleh dari laporan belanja modal kegiatan proyek

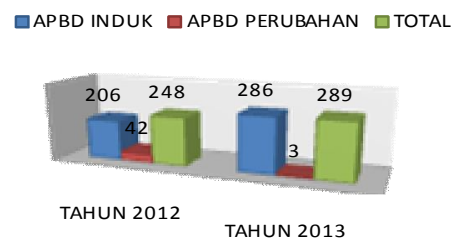

Gambar 2 Jumlah Kegiatan Proyek Konstruksi konstruksi Pemerintah Kabupaten Badung TA 2012 - TA 2013 diperoleh:

Kegiatan proyek konstruksi di Kabupaten Badung TA 2012 - TA 2013 didominasi oleh Dinas Bina Marga \& Pengairan sebanyak 197 paket (36,69\%), kemudian Dinas Cipta Karya sebanyak 171 paket $(31,84 \%)$ dan Dinas Pendidikan, Pemuda \& Olah Raga sebanyak 118 paket $(21,97 \%)$.

Sedangkan untuk penyerapan anggaran, dengan membandingkan nilai kontrak dan realisasinya. Karena tidak adanya aturan yang baku dalam mengukur tingkat penyerapan anggaran, maka sebagai acuan dalam menganalisis penyerapan anggaran proyek konstruksi, diperoleh berdasarkan dari hasil pengamatan, in-depth interview serta kajian pustaka yang dilakukan. Maka acuan penyerapan yang baik serta digunakan sebagai rencana penyerapan anggaran. 


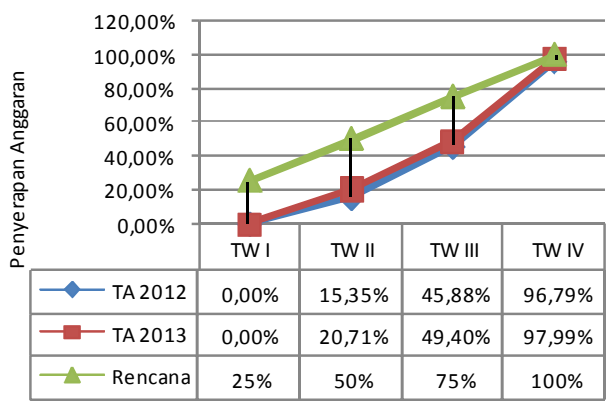

Gambar 3 Penyerapan Anggaran Proyek Konstruksi TA 2012 - TA 2013

Secara keseluruhan seperti pada grafik, terlihat penyerapan anggaran proyek konstruksi Pemerintah Kabupaten Badung pada Tahun Anggaran 2012 - Tahun Anggaran 2013 masih kurang optimal dari rencana yang telah ditentukan. Ini terlihat dari lambatnya penyerapan anggaran dan menumpuknya penyerapan anggaran pada akhir tahun. Ini menandakan bahwa proyek konstruksi tetap masih banyak yang dikebut pekerjaannya mendekati akhir tahun. Tentunya ini akan berdampak bagi kualitas proyek konstruksi menjadi kurang memadai.

Tetapi jika dibandingkan dengan penyerapan anggaran tahun sebelumnya yang menggunakan sistem pengadaan konvensional, penyerapan anggaran TA 2012 - 2013 dengan menggunakan sistem e-procurement telah mengalami peningkatan yang cukup signifikan.

\section{Analisis Faktor}

Dari jawaban responden dilakukan analisis faktor menggunakan SPSS versi 15.0 yaitu:

1) Memilih variabel yang layak untuk analisis faktor

Nilai besaran Bartlett's Test of Sphericity adalah dengan Significance yang lebih kecil dari 0,05, nilai Kaiser-Meyer-Olkin (KMO) > 0,5 dan uji Measures of Sampling Adequacy (MSA) dengan nilai $\geq 0,5$. Dari hasil analisa diperoleh: Nilai besaran Bartlett's Test of Sphericty adalah Significance sebesar 0,000 dan Nilai Kaiser-Meyer-Olkin (KMO) adalah sebesar 0,676.

Nilai Measures of Sampling Adequacy (MSA) dari analisis diperoleh seluruh variabel telah memenuhi syarat kelayakan varibel untuk dapat dianalisis lebih lanjut. Dengan nilai MSA $\geq 0,5$, menunjukkan tidak ada variabel yang dibuang.
2) Ekstraksi variabel menjadi kelompok faktor

Jumlah faktor yang terbentuk ditentukan dari eigen value. Eigen value harus lebih besar atau sama dengan 1. Eigen value dibawah 1 tidak dapat digunakan dalam menghitung jumlah faktor yang terbentuk.

Dengan menggunakan metode Principal Component Analysis (PCA) diperoleh 5 (lima) faktor yang mempengaruhi lambatnya penyerapan anggaran Pemerintah Kabupaten Badung. Kelima faktor tersebut dapat menjelaskan semua varian yang ada dalam data, yaitu sebesar 78,764\%.

Tabel 4 Faktor - Faktor yang mempengaruhi Penyerapan Anggaran Pemkab. Badung

\begin{tabular}{cccc}
\hline Faktor & $\begin{array}{c}\text { Eigen } \\
\text { Value }\end{array}$ & $\begin{array}{c}\text { \% of } \\
\text { Variance }\end{array}$ & $\begin{array}{c}\text { Commulative of } \\
\text { Variance } \\
\text { (\%) }\end{array}$ \\
\hline 1 & 9,957 & 26,202 & 26,202 \\
2 & 7,924 & 20,852 & 47,054 \\
3 & 5,183 & 13,640 & 60,694 \\
4 & 4,205 & 11,067 & 71,760 \\
5 & 2,661 & 7,003 & 78,764 \\
\hline \multicolumn{2}{l}{ Sumber: Hasil analisis dengan SPSS }
\end{tabular}

\section{3) Rotasi faktor}

Kemudian dilanjutkan penyederhanaan dengan rotasi kelompok faktor yang menghasilkan matriks komponen rotasi (Rotated Component Matrix) untuk mempermudah interprestasi faktor. Rotasi faktor menggunakan rotasi Varimax karena memberikan hasil yang lebih baik dibandingkan dengan teknik rotasi yang lain. Hasil dari rotasi faktor diperoleh:

(a) Faktor Pertama

Memiliki eigen value 9,957 dan variance 26,202\%. Faktor dibentuk oleh 12 variabel, yaitu: (1) Ketakutan dan kehati-hatian PA/KPA dalam melaksanakan kegiatan pengadaan (loading factor 0,915); (2) Adanya perubahan paket pekerjaan oleh PA/KPA (0,899); (3) Lambatnya proses penyusunan HPS oleh PPK (0,883); (4) Kurang lengkapnya dokumen yang dimiliki PPK untuk pengadaan $(0,873)$; (5) Ketakutan dan kehatihatian PPK/PPTK dalam melaksanakan kegiatan pengadaan $(0,855)$; (6) Adanya perubahan paket pekerjaan oleh PPK $(0,854)$; (7) Lamanya proses penyiapan dokumen pengadaan oleh ULP (0,850); (8) Lambatnya proses pengadaan di ULP akibat adanya gagal lelang/tender ulang $(0,834) ;(9)$ Adanya rangkap tugas panitia pengadaan/ULP dengan tugas kedinasan $(0,826)$; (10) Kesalahan penafsiran terhadap isi peraturan pengadaan yang berlaku oleh panitia pengadaan/ULP 
(0,811); (11) Ketakutan dan kehati-hatian panitia pengadaan/ULP dalam melaksanakan kegiatan pengadaan $(0,811)$; dan (12) Adanya perubahan paket pekerjaan ketika dalam proses pengadaan di ULP $(0,791)$.

Ini berarti kelompok faktor I pengaruhnya sangat tinggi terhadap lambatnya penyerapan anggaran. Faktor dominan pada kelompok faktor I adalah ketakutan dan kehati-hatian para pihak yang terlibat dalam melaksanakan kegiatan pengadaan. Hal ini lebih menjelaskan lambatnya penyerapan anggaran yang terjadi. Sikap ketakutan dan kehati-hatian ini menjadikan proyek konstruksi menjadi terlambat untuk dimulai pengerjaannya. Kelompok faktor ini dinamakan Faktor Internal Pelaksana Pengadaan.

\section{(b) Faktor Kedua}

Memiliki eigen value 7,924 dan variance 20,852 \%. Dibentuk oleh 10 variabel, yaitu: (1) SDM sebagai pejabat PA/KPA kurang kompeten (0,939); (2) Kesulitan PPK dalam menentukan HPS karena kurangnya keahlian (0,913); (3) SDM sebagai PPK/PPTK kurang kompeten $(0,895)$; (4) Adanya perubahan jadwal kegiatan oleh PPK (0,890); (5) Lambatnya proses pengadaan di ULP akibat lelang masih dalam masa sanggah dan proses hukum (0,889); (6) SDM sebagai panitia pengadaan/ULP kurang kompeten $(0,876)$; (7) Lambatnya proses pengadaan karena jumlah SDM di ULP kurang memadai $(0,875)$; (8) Adanya perubahan jadwal kegiatan oleh panitia pengadaan/ULP $(0,865)$; (9) SDM sebagai PPHP kurang kompeten $(0,839)$; dan (10) Keterlambatan penyampaian laporan karena jumlah SDM sebagai PPHP kurang memadai $(0,766)$.

Kelompok faktor II pengaruhnya tinggi terhadap lambatnya penyerapan anggaran. Faktor dominan pada kelompok faktor ini adalah kurang kompetennya SDM para pihak yang terlibat dalam melaksanakan kegiatan pengadaan. Selanjutnya dinamakan Faktor Kompetensi Pelaksana Pengadaan.

\section{(c) Faktor Ketiga}

Eigen value 5,183 dan variance 13,640 $\%$. Terbentuk dari 7 variabel, yaitu: (1) DIPA terlambat diterima oleh PA/KPA $(0,909)$; (2) Keterlambatan dalam penetapan PPK oleh PA/KPA (0,903); (3) Keterlambatan dalam penandatanganan kontrak oleh PPK $(0,898)$; (4) Keterbatasan panitia pengadaan/ULP yang bersertifikat $(0,889)$; (5) Keengganan untuk menjabat panitia pengadaan/ULP $(0,865) ;(6)$
Tidak seimbangnya risiko pekerjaan dengan imbalan yang diterima oleh panitia pengadaan/ULP $(0,854) ; \quad$ (7) Terlambatnya penyusunan jadwal pelaksanaan pengadaan oleh panitia pengadaan/ULP $(0,847)$.

Kelompok faktor III pengaruhnya sedang terhadap lambatnya penyerapan anggaran. Dengan faktor dominan pada kelompok ini adalah keterlambatan para pihak yang terlibat dalam melaksanakan proses pengadaan. Kelompok ini dinamakan Faktor Pelaksanaan Pengadaan.

\section{(d) Faktor Keempat}

Faktor ini memiliki eigen value 4,205 dan variance sebesar $11,067 \%$. Faktor ini dibentuk oleh 5 variabel, yaitu: (1) Kurangnya sosialisasi tata cara pengadaan berdasarkan peraturan yang berlaku kepada PA/KPA (0,903); (2) Kurangnya sosialisasi tata cara pengadaan berdasarkan peraturan yang berlaku kepada PPK/PPTK $(0,895)$; (3) Keterbatasan pejabat yang bersertifikat untuk PPK/PPTK $(0,892)$; (4) Kurangnya sosialisasi tata cara pengadaan berdasarkan peraturan yang berlaku kepada panitia pengadaan/ULP $(0,877)$; dan (5) Kurangnya sosialisasi tata cara pengadaan berdasarkan peraturan yang berlaku kepada PPHP $(0,862)$.

Sedangkan kelompok faktor IV kurang berpengaruh terhadap lambatnya penyerapan anggaran. Faktor dominannya adalah kurangnya sosialisasi tata cara pengadaan terhadap para pihak yang terlibat dalam melaksanakan kegiatan proyek konstruksi. Untuk selanjutnya dinamakan Faktor Sosialisasi Pelaksanaan Pengadaan.

\section{(e) Faktor Kelima}

Faktor ini memiliki eigen value sebesar 2,661 dan variance sebesar 7,003\%. Dibentuk oleh 4 variabel, yaitu: (1) Keterlambatan dalam penyusunan laporan kegiatan oleh PPK/PPTK $(0,889)$; (2) Keterlambatan penyusunan Kerangka Acuan Kerja oleh PPK $(0,887)$; (3) Keterlambatan dalam penyusunan laporan kegiatan oleh ULP (0,851); (4) Keterlambatan dalam penyusunan laporan kegiatan oleh PPHP $(0,818)$.

Kelompok faktor terakhir, pengaruhnya sangat kecil terhadap lambatnya penyerapan anggaran dengan faktor dominan pada kelompok faktor $\mathrm{V}$ adalah keterlambatan penyusunan laporan oleh para pihak yang terlibat dalam kegiatan proyek konstruksi. Yang terakhir, kelompok faktor ini dinamakan Faktor Evaluasi Pelaksanaan Pengadaan. 


\section{Upaya - Upaya untuk Meningkatkan Penyerapan Anggaran}

Dari 6 upaya pada sistem pengadaan proyek konstruksi untuk meningkatkan penyerapan anggaran yang diajukan pada responden untuk dipilih sebagai cara paling efektif, diperoleh tiga upaya dengan pemilih terbanyak. Pertama, upaya kedua yaitu menetapkan standar komunikasi, koordinasi dan sinkronisasi dalam pengadaan proyek konstruksi dengan semua pihak yang terlibat di dalamnya, dari 60 orang responden, 23 orang $(38,33 \%)$ memilih upaya 2 menjadi cara yang paling efektif pertama.

Sebagai cara efektif kedua, dari 60 orang responden yang dimintai keterangan, sebanyak 19 orang $(31,67 \%)$ memilih upaya 1 menjadi cara yang paling efektif kedua untuk meningkatkan penyerapan anggaran yaitu perencanaan pengadaan yang sistematis dan membuat SOP yang baku sesuai dengan peraturan yang berlaku.

Dan upaya kelima dari yang diajukan yaitu mengadakan sosialisasi peraturan perundangan mengenai pengadaan bagi semua pihak yang melakukan kegiatan pengadaan proyek konstruksi, menjadi cara paling efektif ketiga dengan jumlah pemilih sebanyak 20 orang $(33,33 \%)$.

\section{SIMPULAN DAN SARAN}

\section{Simpulan}

Berdasarkan hasil penelitian yang telah dilakukan mengenai analisis sistem pengadaan proyek konstruksi terhadap penyerapan anggaran Pemerintah Kabupaten Badung, maka kesimpulan yang diperoleh untuk menjawab pokok permasalahan adalah:

1) Tingkat penyerapan anggaran proyek konstruksi Pemerintah Kabupaten Badung Tahun Anggaran 2012 - Tahun Anggaran 2013 masih belum sesuai dengan rencana tetapi sudah lebih meningkat dibandingkan tahun anggaran sebelumnya. Setelah penggunaan sistem pengadaan e-procurement, terjadi peningkatan penyerapan anggaran antara $10 \%$ sampai dengan $20 \%$ dibandingkan dengan tahun anggaran sebelumnya yang menggunakan sistem pengadaan konvensional.

2) Berdasarkan analisis faktor, maka diperoleh faktor-faktor pada sistem pengadaan proyek konstruksi yang paling mempengaruhi lambatnya penyerapan anggaran Pemerintah Kabupaten Badung yaitu ketakutan dan kehati-hatian para pihak dalam melaksanakan kegiatan pengadaan, adanya perubahan paket kegiatan, lambatnya penyusunan HPS, kurang lengkapnya dokumen pengadaan, kesalahan penafsiran peraturan pengadaan dan lambatnya proses pengadaan.

3) Upaya yang paling efektif pada sistem pengadaan proyek konstruksi untuk meningkatkan penyerapan anggaran Pemerintah Kabupaten Badung berdasarkan jawaban responden adalah menetapkan standar komunikasi, koordinasi dan sinkronisasi dalam pengadaan proyek konstruksi dengan semua pihak yang terlibat didalamnya. Dengan ini diharapkan dapat memberikan efek positif pada semua pihak yang terlibat, sehingga dapat melakukan proses pengadaan dengan baik dan tidak ada keragu-raguan dalam mengambil keputusan sehingga proyek dapat berjalan sesuai dengan waktu yang telah direncanakan dan penyerapan anggaran dapat berjalan optimal.

\section{Saran}

Dari hasil penelitian dan pembahasan yang telah dianalisis, maka dapat diberikan beberapa saran sebagai berikut:

1) Untuk meningkatkan penyerapan anggaran proyek konstruksi pada tahuntahun anggaran berikutnya, disarankan pada pihak-pihak yang terlibat dalam pengadaan proyek konstruksi agar kegiatan pengadaan khususnya proyek konstruksi dapat dilakukan lebih awal (pada awal tahun) agar kegiatan proyek konstruksi dapat segera terealisasikan sehingga tidak adanya lagi penumpukkan pada akhir tahun. Dengan pengerjaan proyek konstruksi yang baik tentunya kualitas yang dihasilkan akan sesuai dengan yang diharapkan.

2) Karena ketakutan dan kehati-hatian dalam melaksanakan kegiatan pengadaan yang terjadi pada hampir disemua pihak yang terlibat pada pengadaan proyek konstruksi menjadi faktor utama dalam lambatnya penyerapan anggaran, maka disarankan agar para pelaksana kegiatan pengadaan proyek konstruksi selalu berpedoman pada peraturan perundanganundangan yang berlaku dalam melaksanakan kegiatan pengadaan.

3) Pimpinan sebaiknya mempertimbangkan kompetensi pihak-pihak yang terlibat langsung dalam proses pengadaan proyek 
konstruksi sehingga dapat melaksanakan kegiatan proyek konstruksi secara optimal.

4) Pemerintah agar segera menerbitkan $e$ catalog (catalog elektronik) untuk mempermudah dalam penentuan spesifikasi teknis dan standar harga yang digunakan dalam penyusunan HPS.

5) Meningkatkan standar komunikasi, koordinasi dan sinkronisasi dalam pengadaan proyek konstruksi oleh semua pihak yang terlibat didalamnya agar semua permasalahan internal pelaksana pengadaan dapat diatasi dan kegiatan proyek konstruksi dapat berjalan optimal sehingga keterlambatan penyerapan anggaran dapat diminimalisir serta sesuai dengan rencana yang telah ditentukan.

\section{DAFTAR PUSTAKA}

Anonim. 2012. Peraturan Presiden No.70 Tahun 2012 Tentang Perubahan Kedua Atas Peraturan Presiden No.54 Tahun 2010 Tentang Pengadaan Barang/Jasa Pemerintah.

Anonim. 2012. Perka LKPP No.14 Tahun 2012 Tentang Pengadaan Barang/Jasa Pemerintah.

Arikunto, S. 2006. Manajemen Penelitian. Cetakan ketujuh. Jakarta: PT. Asdi Mahasatya.

Ervianto, W.I. 2005. Manajemen Proyek Konstruksi. Edisi Revisi. Yogyakarta: Andi.

Hair, J.F. Anderson, R.E., Tantham, R.L., Black, W.C. 1998. Multivariate Data Analysis. Edisi Kelima. Prentice Hall International, Inc.

Mardiasmo. 2002. Akuntansi Sektor Publik. Yogyakarta: Andi.

Priyatno, D. 2010. Paham Analisa Statistik Data dengan SPSS. Yogyakarta: MediaKom.

Sugiyono. 2013. Metode Penelitian Bisnis. Cetakan ke-17. Bandung: Alfabeta. 